\title{
Clarifying the present state of and trends in Comparative Education from an analysis of journal articles
}

\author{
Charl C. Wolhuter (North-West University, South Africa)
}

\begin{abstract}
The aim of this research is to explicate the present state of and developments within the field of Comparative Education, by means of an analysis of articles published in Canadian and International Education and the Comparative Education Review, two eminent journals in the field. The following aspects of articles published in the two journals, since their inception till the end of 2006, were analyzed:

- levels of analysis of articles

- $\quad$ number of units covered by articles

- $\quad$ geographical areas which articles deal with

- $\quad$ modes of education articles deal with and

- themes/topics focused on.

From the analysis, two features of the field became visible. On the one hand a striking consistency, on the other hand potential for a considerable broadening of levels of analysis, of geographical areas, and of modes of education. Theoreticians in the field make reasoned cases for such broadening, and articles analyzed revealed that incipient moves towards them are taking place. However, much scope for the expansion of the field along these lines exists. Some of these are pointed out.
\end{abstract}

\section{Résumé}

Cette recherche analyse plusieurs articles de deux revues éminentes, l'Education canadienne et Internationale et la revue Comparative Education Review dont le but sera d'expliquer l'état présent ainsi que l'évolution des recherches en Éducation Comparée. Les articles ont été choisis, depuis la création des revues jusqu'à la fin de 2006, sur la base des caractéristiques suivantes :

- $\quad$ Niveau d'analyse de l'article;

- Quantité d'éléments couverts par article;

- Zones géographiques visées par les articles ;

- Méthodologies éducatives visées par l'article;

- Thèmes/sujets analysés.

L'analyse présente deux caractéristiques principales. D'un côté, il existe une consistance frappante, et de l'autre, un grand potentiel pour diversifier d'avantage les différents niveaux d'analyse, les zones géographiques, ainsi que les méthodologies éducatives visées. Les spécialistes du domaine acceptent cette diversification. Plusieurs articles analysés démontrent qu'un mouvement récent de diversification est en train de se développer. Les objectifs de développement doivent cependant être mieux définis. Quelques possibilités sont indiquées dans cet article. 


\section{THE PERSISTENT ASSIGNMENT OF REDUCING THE FACELESSNESS OF COMPARATIVE EDUCATION}

Theoreticians of Comparative Education frequently point to the intractable identity of the field, rendered by its diversity, richness and variety (for example, see: Phillips and Schweisfurth, 2006:3). This explains the constant quest for an overview of the field, in order to acquire an intellectual grip on the field (for example, see: Phillips and Schweisfurth, 2006:4). Discussions of what constitutes Comparative Education have had a long history. It has been a matter of some disputation (for example the well-known case when participants at the founding conference of the Comparative Education Society of Europe were split right down the middle of this issue (Vos \& Barnard, 1984:12-14), at times quite acrimonious, and sometimes even humorous. It is a recurring theme in Comparative and International Education Societies' (CIES) presidential addresses. In his address, Harold Noah (1974:342) explains the position of Comparative Education as follows: comparativists have made the comparative and international study of education their own area of specialization. They constantly have to embrace and to incorporate the scholarly work of scholars from other disciplines who, finding that the phenomena of education and schooling provide a host of problems of exceptional interest, often seize on comparative analyses of education to advance understanding in their own fields (Noah, 1974:342). This makes for a dynamic and expanding, if diffuse and very difficult to encapsulate field. Ultimately what will probably be subscribed to by many, is Erwin Epstein's remark, reputedly made at one CIES conference, after a particularly furious debate, that maybe we could agree that Comparative Education is what those who claim to engage in it to do. If so, then the collection of articles published in Comparative Education journals, can provide the material for a credible painting of the face of Comparative Education.

This article attempts to clarify the present state of and developments within the field of Comparative Education, by means of analysis of articles published in two eminent journals of the field, the Comparative Education Review and Canadian and International Education.

\section{RESEARCH METHOD}

The following aspects of articles which were published in the volumes of the Comparative Education Review and Canadian and International Education since their inception (respectively 1957 and 1972) till 2006 were analyzed:

- level of analysis of articles

- number of units covered by articles

- geographical areas which articles deal with

- themes/topics focuses on 


\section{LEVELS OF ANALYSIS}

In investigating the level of analysis present in articles, the model of Mark Bray and R. Murray Thomas (1995) was used. Bray and Thomas (1995:475) distinguish between the following levels of comparative educational studies: level 1: world regions/continents, level 2: countries, level 3: states/provinces, level 4: districts, level 5: schools, level 6: classrooms, and level 7: individuals. For this research the first level was more finely calibrated into three levels: world, super-continental groupings, and continents. This was done in order to record world/global studies, as well as super-continental groupings (such as developing countries).

The percentages of articles published in Canadian and International Education falling in each of these level categories, for five year periods, are presented in table 1 .

The country or nation-state or national education system was historically the prime focus of Comparative Education scholarship (see Bray and Kai, 2007:132) in both journals throughout the histories of the two journals. The twenty-first century trend of the fading of the omnipotent nation-state of the preceding two centuries and the shifting of the locus of control into two opposite directions - upwards to larger levels (globalization and super-national groupings), and downwards to smaller levels (decentralization, localization, individualization; the empowerment of minority groups) had not yet dethroned the nation state as the principal unit of analysis in Comparative Education scholarship. Time will tell to what extent the dip it took in volumes 31-35 of Canadian and International Education (see table 1) was ephemeral or whether it signaled a permanent shift. In the five years up to 2006 a similar, albeit much weaker trend is visible in the Comparative Education Review (in the five-year period up to 2006, the nation state accounts for $66 \%$ of articles published in the Comparative Education Review, compared to $78 \%$ during the five years before that). In both journals, whatever shift there is, is toward smaller levels, especially towards the state/province level. The levels of the institution and the classroom have in both journals just started to appear during the last five years up to 2006; while the individual is totally absent.

Table 1. Percentages of Articles Published in the Canadian and International Education Dealing with Various Levels of Educational Enterprises

\begin{tabular}{|l|c|c|c|c|c|c|c|}
\hline $\begin{array}{l}\text { Volumes of } \\
\text { Review: } \\
\text { Levels: }\end{array}$ & $\mathbf{1 - 5}$ & $\mathbf{6 - 1 0}$ & $\mathbf{1 1 - 1 5}$ & $\mathbf{1 6 - 2 0}$ & $\mathbf{2 1 - 2 5}$ & $\mathbf{2 6 - 3 0}$ & $\mathbf{3 1 - 3 5}$ \\
\hline World & 4 & 4 & 12 & 3 & 5 & 0 & 3 \\
\hline $\begin{array}{l}\text { Super } \\
\text { Continent }\end{array}$ & 9 & 6 & 5 & 11 & 12 & 0 & 3 \\
\hline Continent & 4 & 2 & 7 & 0 & 0 & 0 & 5 \\
\hline $\begin{array}{l}\text { Supra } \\
\text { Country }\end{array}$ & 2 & 6 & 0 & 2 & 2 & 2 & 2 \\
\hline
\end{tabular}




\begin{tabular}{|l|c|c|c|c|c|c|c|}
\hline Country & 64 & 56 & 51 & 76 & 81 & 77 & 38 \\
\hline $\begin{array}{l}\text { Province/Cat } \\
\text { egory }\end{array}$ & 13 & 14 & 19 & 8 & 0 & 16 & 38 \\
\hline District/City & 2 & 8 & 3 & 0 & 0 & 5 & 0 \\
\hline Institution & 2 & 4 & 3 & 0 & 0 & 0 & 4 \\
\hline Class & 0 & 0 & 0 & 0 & 0 & 0 & 4 \\
\hline Individual & 0 & 0 & 0 & 0 & 0 & 0 & 0 \\
\hline $\begin{array}{l}\text { Multiple } \\
\text { Level }\end{array}$ & 0 & 0 & 0 & 0 & 0 & 0 & 3 \\
\hline Comp Educ & 14 & 16 & 22 & 26 & 17 & 27 & 26 \\
\hline
\end{tabular}

The bottom row denotes the percentages of articles which dealt with Comparative Education per se, i.e. methodological issues, philosophical foundation, etc. These articles were not included in calculating the percentage distribution of the levels.

\section{Number of units covered by articles}

At all levels single unit studies dominate with respect to both journals. This is also a continuation of a long-standing feature of Comparative Education. The contention among comparativists is that single-unit studies qualified as comparative research if it hooks onto and builds on to the set of concepts making up the theoretical edifice of the field (concepts such as "schooled unemployment" or "socio-economic reproduction"). At the same time, however, comparative studies in the fullest sense of the word (i.e. two-unit plus studies) can, by means of contrasts and highlighting of similarities, reveal societal-contextual-educational interrelationships like no single-unit study can. Heed should also be paid to Arnove's (2001:496) caution as to the danger to generalize from one case. Therefore the move away from single unit studies in the latest batch of Canadian and International Education volumes (see table 2) - especially if it eventually proves to be not a temporary trend - can be regarded as a wholesome development. The same trend is visible in the Comparative Education Review, albeit once again, not as strong as in Canadian and International_Education. For example, on country level, single-unit studies constitute $100 \%$ and $71 \%$ of articles in respectively the penultimate and latest batches (see table 2). In the Comparative Education Review, the corresponding figures are $83 \%$ and $71 \%$. 
Table 2 Percentages of Articles in the Canadian and International Education Covering Various Numbers of Units (Each cell adds up to $100 \%$ ) (n/a: not applicable, signalling there were no articles published on level in volumes, compare with table 1)

\begin{tabular}{|c|c|c|c|c|c|c|c|}
\hline $\begin{array}{l}\text { Volumes of } \\
\text { Review: } \\
\text { Levels: }\end{array}$ & $1-5$ & $6-10$ & 11-15 & $16-20$ & $21-25$ & $26-30$ & 31-35 \\
\hline $\begin{array}{l}\text { World: } \\
1 \text { unit }\end{array}$ & 100 & 100 & 100 & 100 & 100 & $\mathrm{n} / \mathrm{a}$ & 100 \\
\hline $\begin{array}{l}\text { Super Continent: } \\
1 \text { unit } \\
2 \text { units }\end{array}$ & $\begin{array}{l}88 \\
12 \\
\end{array}$ & $\begin{array}{c}100 \\
0\end{array}$ & $\begin{array}{c}100 \\
0\end{array}$ & $\begin{array}{c}100 \\
0\end{array}$ & $\begin{array}{c}100 \\
0\end{array}$ & $\begin{array}{c}\mathrm{n} / \mathrm{a} \\
-\end{array}$ & $\begin{array}{c}100 \\
-0\end{array}$ \\
\hline $\begin{array}{l}\text { Continent: } \\
1 \text { unit } \\
2 \text { units } \\
3+\text { units } \\
\end{array}$ & $\begin{array}{c}100 \\
0 \\
0\end{array}$ & $\begin{array}{c}100 \\
0 \\
0\end{array}$ & $\begin{array}{c}100 \\
0 \\
0\end{array}$ & $\begin{array}{c}\mathrm{n} / \mathrm{a} \\
- \\
-\end{array}$ & $\begin{array}{c}\mathrm{n} / \mathrm{a} \\
- \\
-\end{array}$ & $\begin{array}{c}\mathrm{n} / \mathrm{a} \\
- \\
-\end{array}$ & $\begin{array}{c}100 \\
0 \\
0\end{array}$ \\
\hline $\begin{array}{l}\text { Supra Country: } \\
1 \text { unit } \\
2 \text { units } \\
3+\text { units }\end{array}$ & $\begin{array}{c}100 \\
0 \\
0\end{array}$ & $\begin{array}{c}100 \\
0 \\
0\end{array}$ & $\begin{array}{c}-\mathrm{n} / \mathrm{a} \\
- \\
-\end{array}$ & $\begin{array}{c}100 \\
- \\
-\end{array}$ & $\begin{array}{c}100 \mathrm{a} \\
- \\
-\end{array}$ & $\begin{array}{c}100 \\
- \\
-\end{array}$ & $\begin{array}{c}100 \\
- \\
-\end{array}$ \\
\hline $\begin{array}{l}\text { Country } \\
1 \text { unit } \\
2 \text { units } \\
3+\text { units }\end{array}$ & $\begin{array}{c}74 \\
19 \\
7\end{array}$ & $\begin{array}{c}86 \\
11 \\
3\end{array}$ & $\begin{array}{c}88 \\
6 \\
6\end{array}$ & $\begin{array}{c}86 \\
3 \\
11\end{array}$ & $\begin{array}{c}89 \\
8 \\
3\end{array}$ & $\begin{array}{c}100 \\
0 \\
0\end{array}$ & $\begin{array}{c}71 \\
24 \\
5\end{array}$ \\
\hline $\begin{array}{l}\text { Province/ Catego- } \\
\text { ry } \\
1 \text { unit } \\
2 \text { units } \\
3 \text { +units } \\
\end{array}$ & $\begin{array}{c}91 \\
9 \\
0\end{array}$ & $\begin{array}{c}100 \\
0 \\
0\end{array}$ & $\begin{array}{c}100 \\
0 \\
0\end{array}$ & $\begin{array}{c}100 \\
- \\
-\end{array}$ & $\begin{array}{c}\mathrm{n} / \mathrm{a} \\
- \\
-\end{array}$ & $\begin{array}{c}100 \\
0 \\
0\end{array}$ & $\begin{array}{c}77 \\
8 \\
15\end{array}$ \\
\hline $\begin{array}{l}\text { District } \\
1 \text { unit } \\
2 \text { units } \\
\text { 3+units }\end{array}$ & $\begin{array}{c}100 \\
0 \\
0\end{array}$ & $\begin{array}{c}100 \\
0 \\
0\end{array}$ & $\begin{array}{c}100 \\
0 \\
0\end{array}$ & $\mathrm{n} / \mathrm{a}$ & $\mathrm{n} / \mathrm{a}$ & $\begin{array}{c}100 \\
0 \\
0\end{array}$ & $\begin{array}{c}\mathrm{n} / \mathrm{a} \\
- \\
-\end{array}$ \\
\hline $\begin{array}{l}\text { Class } \\
1 \text { unit } \\
2 \text { units } \\
3+\text { units }\end{array}$ & $\mathrm{n} / \mathrm{a}$ & $\mathrm{n} / \mathrm{a}$ & $\mathrm{n} / \mathrm{a}$ & $\mathrm{n} / \mathrm{a}$ & $\mathrm{n} / \mathrm{a}$ & $\mathrm{n} / \mathrm{a}$ & $\begin{array}{c}100 \\
0 \\
0\end{array}$ \\
\hline $\begin{array}{l}\text { Multiple } \\
\text { Levels } \\
2 \text { units } \\
\text { 3+units }\end{array}$ & $\mathrm{n} / \mathrm{a}$ & $\mathrm{n} / \mathrm{a}$ & $\mathrm{n} / \mathrm{a}$ & $\mathrm{n} / \mathrm{a}$ & $\mathrm{n} / \mathrm{a}$ & $\mathrm{n} / \mathrm{a}$ & $\begin{array}{c}100 \\
\mathrm{o}\end{array}$ \\
\hline
\end{tabular}

94 Canadian and International Education Vol. 39 no. 2 - June 2010 


\section{Geographical areas}

The geographical areas on which Canadian and International Education articles on the levels of super-continent and continent levels focus are presented in table 3 , those on supra-country in table 4 , and those on country and sub-country levels in table 5. Table 6 shows how the different world regions are presented in Canadian and International Education and table 7 presents a summary of which areas are compared with each other in articles published in that journal. On the super continent and continent levels, articles on the developing countries by far exceed those dealing with the developed world (see table 3 ). The same pattern is evident in the Comparative Education Review, and might be related to the large number of comparativists engaged in developmental and humanitarian work in the developing world, and also American and Canadian governmental and non-governmental organizations' interest in the role of education in assistance to developing countries.

Table 3. Number of Articles in the Canadian and International Education Focusing on the Levels of Super-Continent and Continent Covering Various Geographical Areas (-:not applicable, signalling there were no articles published on level and Area in volumes)

\begin{tabular}{|c|c|c|c|c|c|c|c|}
\hline $\begin{array}{l}\text { Volumes } \\
\text { Area }\end{array}$ & $1-5$ & $6-10$ & $11-15$ & $16-20$ & $21-25$ & $26-30$ & $31-35$ \\
\hline $\begin{array}{l}\text { Super Conti- } \\
\text { nent: } \\
\text { Developed } \\
\text { Countries }\end{array}$ & - & 1 & - & - & - & - & - \\
\hline $\begin{array}{l}\text { Developing } \\
\text { Countries }\end{array}$ & 7 & 1 & 2 & 7 & 3 & - & 1 \\
\hline Continent & & & & & & & \\
\hline Africa & - & - & - & - & - & - & - \\
\hline North & - & - & - & - & - & - & 1 \\
\hline America & 1 & - & 1 & - & - & - & - \\
\hline Latin & - & & - & - & - & - & - \\
\hline America & 1 & & 1 & - & - & - & - \\
\hline Asia & & 1 & - & & & & \\
\hline Europe & 1 & - & -- & & & & \\
\hline
\end{tabular}


Table 4. Number of Articles in the Canadian and International Education, Focusing on the Level of Supra Country Covering Various Geographical Areas (-:not applicable, signalling there were no articles published on level and Area in volumes)

\begin{tabular}{|l|c|c|c|c|c|c|c|}
\hline $\begin{array}{l}\text { Volumes } \\
\text { Supra } \\
\text { Country }\end{array}$ & $\mathbf{1 - 5}$ & $\mathbf{6 - 1 0}$ & $\mathbf{1 1 - 1 5}$ & $\mathbf{1 6 - 2 0}$ & $\mathbf{2 1 - 2 5}$ & $\mathbf{2 6 - 3 0}$ & $\mathbf{3 1 - 3 5}$ \\
\hline $\begin{array}{l}\text { Western } \\
\text { Europe }\end{array}$ & - & - & - & 1 & - & 1 & 1 \\
$\begin{array}{l}\text { SubSaharan } \\
\text { Africa }\end{array}$ & 1 & - & - & - & - & - & - \\
$\begin{array}{l}\text { South East } \\
\begin{array}{l}\text { Asia } \\
\text { Transition } \\
\text { Countries }\end{array}\end{array}$ & - & 1 & - & - & - & - & - \\
\hline
\end{tabular}

The rank-order of countries in Canadian and International Education (see table 5) differ from that of the Comparative Education Review. In the first Canada is at the top of the list. Up to the early 1970s the USSR tops the Comparative Education Review list, followed by the USA till the end of the twentieth century, followed by South Africa from 2001 till 2006. These differences might reflect a consistently more inward orientation of Canadian comparativists (rendered by their federal political structure, and the demographics of Canada: the EnglishFrench issue, multicultural population, immigration), compared to a generally more outward orientation of United States' comparativists (except for the postVietnam phase, when they too tended to be more inward-looking). The other countries on the Canadian and International Education list reveal an interest in education from countries which are sources of substantial numbers of recent immigration waves into Canada (e.g. China, India and Poland). In the case of the Comparative Education Review, the collection of countries represented in articles is more globally diffuse. However, for both journals it appears as if lacunae in contemporary Comparative Education scholarship are studies on transitions and studies on education in some states crucially important for world peace. Turning to the first, a long line of comparativists, (e.g. Cowen, 2000; Usarralde, 2002:7; Steiner-Khamsi \& Stolpe, 2004:29-53; Kazamias, 2001; Sweeting, 2007:159; Alexander, 2001:5071; Bray \& Brevskaya, 2001:345; Bray \& Lee, 1997; De Wet \& Wolhuter, 2009) have in recent years pointed to the value of the study of transitions, i.e. where the simultaneous collapse and reconstruction of state apparatus as well as socio-political and education systems take place. Nevertheless, these regions, such as the successor states most of the Eastern European states, notably the Balkan states; as well as countries such as Vietnam and Cambodia, have not risen to being visible on the Comparative Education research agenda. The same applies to states pivotal for global space, such as the Middle Eastern states, Zimbabwe, Sudan and Afghanistan. 
Table 5. Geographical Foci of Articles in the Canadian and International Education on the Levels of Country and Sub-Country. Rank-Order of Frequency of Countries with Ten Highest Frequencies (1 signifying highest frequency, 9 denoting $10^{\text {th }}$ highest frequency)

(Only countries appearing at least twice were considered)

\begin{tabular}{|c|c|c|c|c|c|c|c|}
\hline Volumes & $\mathbf{1 - 5}$ & $\mathbf{6 - 1 0}$ & $\mathbf{1 1 - 1 5}$ & $\mathbf{1 6 - 2 0}$ & $\mathbf{2 1 - 2 5}$ & $\mathbf{2 6 - 3 0}$ & $\mathbf{3 1 - 3 5}$ \\
$\begin{array}{c}\text { Rank } \\
\text { Order }\end{array}$ & & & & & & & \\
$\mathbf{1}$ & Canada & Canada & Canada & Canada & Canada & Canada & Canada \\
$\mathbf{2}$ & Japan & China & China & China & China & HKong & China \\
$\mathbf{3}$ & India & WGerma & & Israel & Poland & China & China \\
$\mathbf{4}$ & China & ny & & UK & Bhutan & India & USA \\
$\mathbf{5}$ & Malawi & India & & Nigeria & UK & Russia & Japan \\
$\mathbf{6}$ & & Israel & & & & Czech & \\
$\mathbf{7}$ & & France & & & & & \\
$\mathbf{8}$ & & Australia & & & & & \\
$\mathbf{9}$ & & USA & & & & & \\
& & & & & & & \\
\hline
\end{tabular}

Table 6. Geographical Spread of Foci of Articles in the Canadian and International Education Review, on the Levels of Country and Sub-Country Rank. Percentages of Articles Focussing on Countries in Various Areas

\begin{tabular}{|l|c|c|c|c|c|c|c|}
\hline $\begin{array}{l}\text { Volumes } \\
\text { Area }\end{array}$ & $\mathbf{1 - 5}$ & $\mathbf{6 - 1 0}$ & $\mathbf{1 1 - 1 5}$ & $\mathbf{1 6 - 2 0}$ & $\mathbf{2 1 - 2 5}$ & $\mathbf{2 6 - 3 0}$ & $\mathbf{3 1 - 3 5}$ \\
\hline North America & 35 & 27 & 46 & 40 & 32 & 36 & 61 \\
\hline $\begin{array}{l}\text { Western Europe and } \\
\text { Israel }\end{array}$ & 14 & 27 & 8 & 12 & 7 & 2 & 5 \\
\hline $\begin{array}{l}\text { EasternEurope and } \\
\text { USSR }\end{array}$ & 3 & 0 & 4 & 0 & 7 & 9 & 0 \\
\hline Islam States* & 2 & 2 & 0 & 2 & 0 & 0 & 3 \\
\hline Asia** & 25 & 30 & 17 & 36 & 17 & 34 & 21 \\
\hline Oceania & 5 & 5 & 4 & 0 & 2 & 2 & 0 \\
\hline $\begin{array}{l}\text { Latin America } \\
\text { and Caribbean }\end{array}$ & 2 & 2 & 13 & 5 & 4 & 2 & 3 \\
\hline Sub-Saharan Africa & 14 & 7 & 8 & 5 & 31 & 15 & 7 \\
\hline
\end{tabular}

*These states are taken to include the Sahara states of Africa, the Middle East (excluding Israel), Turkey, Afghanistan and Pakistan

** Excluding Israel and the Islam states

Another interesting observation is that the pre-eminence given to developing countries on super-continental and continental levels (see table 3 ) is reversed on the country and sub-country levels (see table 5). The same observation holds true with respect to articles published in the Comparative Education Review. It appears as if comparativists engage in broad-sweep macro-analysis studies of developing countries, involving for example statistical indicators of developing countries; but they eschew smaller case, more in-depth studies of education in the developing world. Given the importance of such micro-level studies in 
comprehending what are taking place in schools and classrooms in developing countries, there is much scope for Comparative Education to expand in this direction. Ditto for the dearth of south-south comparative studies (see table 7).

Table 7 Comparisons Between Areas in Articles Published in the Canadian and International Education (articles which compared two or three units)

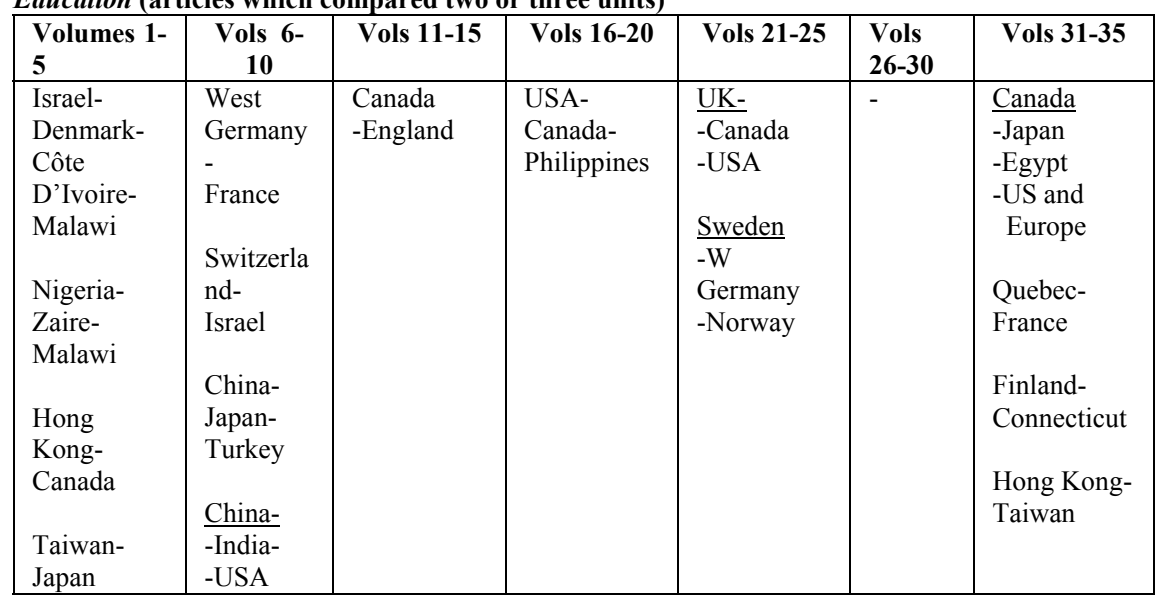

\section{Mode of education}

This article distinguishes between four modes of education. The first three modes are formal education, non-formal education and informal education, all three used as defined by Philip Coombs (1985:20-21). These have been supplemented with a fourth category, named pre-formal education. Pre-formal refers to what children learn from family, especially parental influences in particularly the years before formal schooling commences. At least according to UNESCO's definition of education as “... comprising organized and sustained communication to bring about learning... [and] learning is taken to mean any change in behaviour, knowledge, understanding, skills or capabilities which the learner retains or which cannot be ascribed to physical growth or the development of inherent behaviour patterns" (UNESCO, 1997:10) these influences should be considered part of education. The modes of education upon which articles published in Canadian and International Education focus are presented in table 8 . Throughout the history of the journal, the formal mode is by far the most published. It dominates as strongly the Comparative Education Review. In view of the rising importance of lifelong learning, a large part of which takes place in the mode of non-formal education, as well as the importance attached to family influence and to the early, pre-school years in the life of the child, and the information and communications revolution, the expansion of Comparative Education research to modes of education other than the formal, would be a wholesome development in the field. 
Table 8. Percentages of Articles Published in the Canadian and International Education Review Focusing upon Various Modes of Education

\begin{tabular}{|l|l|l|l|l|l|l|l|}
\hline Volumes of Review & $1-5$ & $6-10$ & $\begin{array}{l}11- \\
15\end{array}$ & $16-20$ & $21-25$ & $26-30$ & $\begin{array}{l}31- \\
35\end{array}$ \\
Mode(s) & 0 & 0 & 0 & 0 & 0 & 0 & 0 \\
\hline Preformal & 93 & 85 & 96 & 94 & 94 & 94 & 92 \\
\hline Formal & 7 & 9 & 2 & 5 & 6 & 3 & 4 \\
\hline Nonformal & 0 & 3 & 2 & 1 & 0 & 3 & 4 \\
\hline Informal & 0 & 3 & 0 & 0 & 0 & 0 & 0 \\
\hline Formal + Nonformal & 0 & 0 & 0 & 0 & 0 & 0 & 0 \\
\hline Formal +Informal & 0 & 0 & 0 & 0 & 0 & 0 & 0 \\
\hline All & 0 & 0 & 0 & 0 & 0 & 0 & 0 \\
\hline Preformal + Formal & 0 & 0 & 0 & 0 & 0 & 0 & 0 \\
\hline Nonformal + Informal & 100 & 100 & 100 & 100 & 100 & 100 & 100 \\
\hline Total & & & & & & & \\
\hline
\end{tabular}

\section{Themes}

Themes covered in articles have been divided into three categories:

- those dealing with societal forces shaping education: those dealing with shaping forces as a whole, geographical factors, demographical factors, technology, language, cultural forces, social forces, economy, political factors, religion/philosophical factors, history, psychological factors, biological factors, morphogenetic factors, foreign education systems and international aid, and global/international forces.

- those dealing with aspects of education systems: system as a whole, policy, objectives, planning, administration and management, finance, institutional fabric and structure, curriculum, evaluation/assessment, achievement, quality, teachers, students, language of instruction, social dynamics/school culture, technical and vocational education, education for students with special needs, alphabetization, extra-curricular activities, teaching methods, support services, physical facilities, parental involvement, textbooks, research, teacher training.

- themes on the effect of education on society: general, demography, technology, language, cultural, social system, economy, politics, values/religion/philosophy, and psychological.

The numbers of articles published in Canadian and International Education dealing with these various themes are presented in tables 9 to 12 (As most articles deal with more than one topic, the totals do not tally with the total number of articles published in Canadian and International Education's volumes 1 to 35$)$. 
Table 9 Numbers of Articles published in Volumes of the Canadian and International Education dealing with shaping forces of education systems

\begin{tabular}{|l|l|l|l|l|l|l|l|}
\hline $\begin{array}{l}\text { Volumes } \\
\text { Factor: }\end{array}$ & $1-5$ & $6-10$ & $11-15$ & $16-20$ & $21-25$ & $26-30$ & $31-35$ \\
\hline General & 0 & 0 & 1 & 0 & 1 & 0 & 0 \\
\hline Geography & 0 & 0 & 0 & 0 & 0 & 0 & 0 \\
\hline Demography & 0 & 0 & 1 & 0 & 1 & 0 & 0 \\
\hline Technology & 0 & 0 & 0 & 0 & 0 & 0 & 0 \\
\hline Language & 0 & 0 & 1 & 0 & 0 & 0 & 0 \\
\hline Cultural & 1 & 4 & 5 & 5 & 0 & 3 & 1 \\
\hline Social & 3 & 3 & 2 & 3 & 2 & 3 & 1 \\
\hline Economy & 0 & 1 & 1 & 0 & 3 & 0 & 0 \\
\hline Politics & 6 & 2 & 4 & 3 & 2 & 1 & 1 \\
\hline Religion/Philosophy & 4 & 1 & 0 & 0 & 4 & 0 & 3 \\
\hline Historical & 2 & 2 & 0 & 0 & 0 & 0 & 0 \\
\hline Psychological & 1 & 0 & 0 & 1 & 0 & 0 & 2 \\
\hline Biological & 0 & 0 & 0 & 0 & 0 & 0 & 0 \\
\hline Morphogenetic & 0 & 0 & 0 & 0 & 0 & 0 & 0 \\
\hline Foreign & 5 & 0 & 1 & 2 & 1 & 4 & 1 \\
\hline Global & 0 & 0 & 1 & 0 & 1 & 0 & 3 \\
\hline Total & 22 & 13 & 17 & 13 & 15 & 11 & 10 \\
\hline
\end{tabular}

As many articles deal with more than one shaping force, the totals of the above read together with the totals appearing in tables 19, 21 and 23 would exceed the number of articles published in the Canadian and International Education.

Table 10 Numbers of Articles published in Volumes of the Canadian and International Education dealing with facets of education (systems)

\begin{tabular}{|c|c|c|c|c|c|c|c|}
\hline $\begin{array}{l}\text { Volumes } \\
\text { Theme }\end{array}$ & $1-5$ & 6-10 & $\begin{array}{ll}11- \\
15\end{array}$ & $\begin{array}{l}16- \\
20\end{array}$ & $\begin{array}{l}21- \\
25 \\
\end{array}$ & $\begin{array}{ll}\text { 26- } \\
\text { 30 }\end{array}$ & $\begin{array}{ll}31- \\
35\end{array}$ \\
\hline System as whole & 1 & 1 & 0 & 1 & 1 & 0 & 0 \\
\hline Policy & 3 & 1 & 4 & 11 & 6 & 4 & 3 \\
\hline Objectives & 1 & 0 & 1 & 0 & 2 & 0 & 1 \\
\hline Planning & 1 & 0 & 0 & 0 & 2 & 0 & 1 \\
\hline Administration \& Management & 1 & 2 & 1 & 4 & 8 & 4 & 9 \\
\hline Financing & 1 & 1 & 1 & 1 & 1 & 0 & 1 \\
\hline Institutional Fabric \& Structure & 1 & 4 & 2 & 0 & 6 & 3 & 0 \\
\hline Curriculum & 6 & 5 & 1 & 3 & 0 & 8 & 1 \\
\hline Assessment & 1 & 0 & 0 & 0 & 0 & 0 & 0 \\
\hline Achievement & 0 & 2 & 0 & 1 & 0 & 0 & 0 \\
\hline Quality & 0 & 0 & 1 & 0 & 0 & 0 & 0 \\
\hline Teachers & 2 & 0 & 1 & 1 & 2 & 1 & 1 \\
\hline Students & 4 & 3 & 3 & 1 & 0 & 6 & 5 \\
\hline Medium (language) & 2 & 1 & 0 & 0 & 0 & 0 & 0 \\
\hline Social dynamics \& School culture & 0 & 0 & 1 & 1 & 0 & 1 & 0 \\
\hline Tech + Vocational Education & 1 & 1 & 0 & 4 & 1 & 1 & 0 \\
\hline Literacy & 1 & 0 & 0 & 0 & 1 & 0 & 0 \\
\hline Extra-curricular Activities & 0 & 0 & 0 & 0 & 0 & 0 & 0 \\
\hline Teaching Methods & 1 & 2 & 2 & 2 & 0 & 1 & 4 \\
\hline Support Services & 0 & 0 & 0 & 0 & 0 & 0 & 0 \\
\hline Physical Facilities & 0 & 0 & 0 & 0 & 0 & 0 & 0 \\
\hline Textbooks & 1 & 0 & 0 & 0 & 0 & 0 & 1 \\
\hline
\end{tabular}




\begin{tabular}{|l|l|l|l|l|l|l|l|}
\hline Research & 0 & 0 & 0 & 4 & 0 & 1 & 0 \\
\hline Teacher Training & 1 & 4 & 0 & 4 & 2 & 5 & 0 \\
\hline Total & 29 & 23 & 18 & 38 & 32 & 35 & 27 \\
\hline
\end{tabular}

As many articles deal with more than one shaping force, the totals of the above, read together with the totals appearing in tables 17, 21 and 23, would exceed the number of articles published in the Canadian and International Education.

Table 11 Numbers of Articles published in Volumes of the Canadian and International Education dealing with the aspects of the effect of education on society

\begin{tabular}{|l|l|l|l|l|l|l|l|}
\hline $\begin{array}{l}\text { Volumes } \\
\text { Aspects }\end{array}$ & $1-5$ & $6-10$ & $11-15$ & $16-20$ & $21-25$ & $26-30$ & $31-35$ \\
\hline General & 0 & 0 & 0 & 0 & 0 & 0 & 0 \\
\hline Demography & 1 & 0 & 0 & 0 & 0 & 0 & 0 \\
\hline Technology & 0 & 0 & 0 & 0 & 0 & 0 & 0 \\
\hline Language & 0 & 0 & 0 & 0 & 0 & 0 & 0 \\
\hline Cultural & 0 & 0 & 0 & 0 & 0 & 0 & 0 \\
\hline Social & 0 & 1 & 1 & 0 & 0 & 1 & 2 \\
\hline Economic & 1 & 2 & 9 & 6 & 0 & 0 & 3 \\
\hline Political & 1 & 2 & 0 & 0 & 0 & 1 & 4 \\
\hline Religion/Phil/Values & 0 & 0 & 1 & 0 & 1 & 0 & 1 \\
\hline Psychological & 0 & 0 & 0 & 0 & 0 & 0 & 0 \\
\hline Total & 3 & 5 & 11 & 6 & 1 & 2 & 8 \\
\hline
\end{tabular}

As many articles deal with more than one shaping force, the totals of the above, read with the totals in tables 16, 18 and 22, would exceed the number of articles published in the Canadian and International Education.

Table 12. Summary of Themes of Articles Published in the Canadian and International Education

Numbers and Percentages of Articles Covering Various Sets of Themes

\begin{tabular}{|l|l|l|l|l|l|l|l|}
\hline Volumes & $1-5$ & $6-10$ & $11-15$ & $16-20$ & $21-25$ & $26-30$ & $31-35$ \\
\hline Number of articles*: & & & & & & & \\
Sets of Themes & 22 & 13 & 17 & 13 & 15 & 11 & 10 \\
Shaping forces & 29 & 23 & 18 & 38 & 32 & 35 & 27 \\
Facets of ed system & 3 & 5 & 11 & 6 & 1 & 2 & 8 \\
Effect of education & & & & & & & \\
\hline $\begin{array}{l}\text { Percentage of articles\#: } \\
\text { Sets of Themes }\end{array}$ & 41 & 32 & 37 & 23 & 31 & 23 & 22 \\
Shaping forces & 53 & 56 & 39 & 67 & 67 & 73 & 60 \\
Facets of Ed system & 6 & 12 & 24 & 10 & 2 & 4 & 18 \\
\hline Effect of education & 6
\end{tabular}

*As many articles deal with more than one shaping force, the totals of the above would exceed the number of articles published in the Canadian and International Education.

\# Articles dealing with methodological-theoretical issues have been excluded from this analysis.

It seems as if the Sadlerian tradition of "things outside the school matter more than things inside the school" (see Noah \& Eckstein, 1969:41) is still running 
strong in Comparative Education. Shaping forces of education attracts a great, though diminishing proposition of attention from comparativists publishing in Canadian and International Education (see table 12). A similar pattern is visible in the Comparative Education Review. Yet, if looking at the paucity of articles on topics such as teaching methods, or school dynamics and school culture (see table 10), a feeling emerge that comparativists are forsaking their subject of study - education - and a case could be made out for shifting the balance more in the direction of intra-education topics.

\section{DISCUSSION}

The above analysis of articles published the past 35 years in Comparative and International Education and past half a century published in the Comparative Education Review reveal two strong trends. On the one hand a conspicuous consistency exists. The nation-state was and still is the preferred level of analysis, and single-unit studies dominate. With respect to the geographical areas upon which articles focus, Canadian and International Education show a strong inward orientation. Those articles that do focus upon foreign education show a predilection for countries which feed the current immigration waves into Canada. The Comparative Education Review is more outward oriented, with a more global mix. By far most articles published in both journals deal with the formal mode of education. Turning to the themes of articles, the focus on societal shaping forces, a focal point of Comparative Education scholarship dating from the days of Michael Sadler (1861-1943) remain strong.

On the other hand, most of the above salient features show signs of a dilution in recent times. Comparativists appear to be slowly heeding to substantiated calls made by theoreticians of Comparative Education to broaden the field of scholarship - to both higher and lower levels than the nation-state, to modes of education other than formal education, and to themes taking enquiry to into education systems, institutions and classrooms. The field can, however, benefit and raise its value by pursuing these lines of expansion more vigorously. More explicitly comparative studies (where two or more units are consciously compared) as well as studies on areas in the world undergoing radical transformation and areas pivotal to global peace would also be a welcome change.

A final remark - this study rests on the postulate that Canadian and International Education) and the Comparative Education Review can be taken as indication of global Comparative Education scholarship. Whole North America (where these two journals are located) is the nerve centre of the international scientific community, Comparative Education there is also shaped by contextual factors - as pointed out in a few places in the article. To gain a more complete and accurate picture of the state of global Comparative Education scholarship, a worthwhile exercise would be to extend this analysis to other journals in the field - Manzon and Bray (2007:358) lists eleven other 
journals devoted exclusively to the field of Comparative Education, located in all parts of the world: Republic of Korea, Japan, China, Spain, Hong-Kong, Southern Africa, Greece, Asia and Australia - New Zealand.

\section{References}

Alexander, R.J. (2001). Border crossings: towards a comparative pedagogy. Comparative Education, Vol. 37, pp. 507-523.

Arnove, R.F. (2001). CIES Facing the Twenty-First Century: Challenges and Contributions Comparative Education Review Vol. 45, No. (4), pp. 477-503.

Bray, M. \& Borevskaya, N. (2001). Financing education in transitional societies: lessons from Russia and China. Comparative Education Review Vol. 45, No.4, pp. 477-503.

Bray, M. \& Jiang, K. (2007). Comparing Systems. In Bray, M; Adamson, B \& Mason, M. (Eds.). Comparative Education Research: Approaches and Methods, Hong Kong: Comparative Education Research Center, The University of Hong Kong, pp. 123-144.

Bray, M. and Lee, W.O. (1997). Editorial introduction. Comparative Education, Vol. 33, pp. 149156.

Bray, M. \& Thomas, R. Murray. (1995). Levels of Comparison in Educational Studies. Harvard Educational Review, Vol. 65, No. 3, pp. 472-490.

Coombs, P.H. (1985). The World Crisis in Education: The view from the eighties. New York: Oxford University Press.

Cowen, R. (2000). “Comparing Futures or Comparing Pasts?”. Comparative Education, Vol. 36, No. 3, pp. 333-342.

De Wet, C. and Wolhuter, C.C. (2009). A transitological study of some South African educational issues. South African Journal of Education, Vol. 29, No.3, pp. 359-376.

Kazamias, A.M. (2001). Re-inventing the historical Comparative Education: reflections on a protean episteme by a contemporary player. Comparative Education, Vol.37, pp. 439-449.

Manzon, M. and Bray, M. (2007). Comparing the Comparers: Patterns, Themes and Interpretations. In: Masemann, V.; Bray, M. and Manzon, M. (Eds.). Common Interests, Uncommon Goals: Histories of the World Council of Comparative Education Societies and its Member,. Hong Kong \& Dordrecht: Comparative Education Research Centre, The University of Hong Kong and Springer, pp. 170-182.

Noah, H.J. (1974). Fast-Fish and Loose-Fish in Comparative Education. Comparative Education Review, Vol. 18, No.3, pp.341-347.

Noah, H.J. \& Eckstain, M.A. (1969. Toward a Science of Comparative Education. London: Macmillan.

Phillips, D. \& Schweisfurth, M. (2006). Comparative and International Education: An Introduction to Theory, Method and Practice. London: Continuum.

Steiner-Khamsi, G. \& Stolpe, I. (2004). Decentralization and recentralization reform in Mongolia: tracing the swing of the pendulum. Comparative Education, Vol. 40, pp.29-53.

Sweeting, A. 2007. Comparing times. In: Bray, M., Adamson, B. \& Mason, M. (Eds.). Comparative Education research. Approaches and methods, Hong Kong: University of Hong Kong.

Usarralde, M.J.M. (2002). Reactions from Comparative Education to Post-modernism: from initial orthodoxy to creative heterodoxy in a globalized world. Revista Electrónica de Investigación Educativa, Vol. 4, pp. 1-12..

Vos, A.J. \& Barnard, S.S. (1984). Comparative and International Education for Student Teachers. Durban: Butterworths.

Charl C. Wolhuter is a professor in Comparative Education at the Potchefstroom Campus of the North West University, South Africa. He is the author of various books and articles on the History of Educatin and Comparative Education. He can be reached at Charl.Wolhuter@nwu.ac.za. 